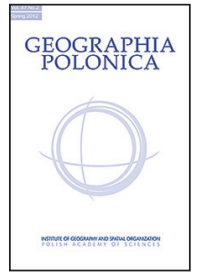

\title{
DIGITAL GEOMORPHOLOGICAL MAP OF POLAND
}

\section{Zofia Rączkowska ${ }^{1}$ - Zbigniew Zwoliński²}

\author{
${ }^{1}$ Institute of Geography and Spatial Organization \\ Polish Academy of Sciences \\ Twarda 51/55, 00-818 Warsaw: Poland \\ e-mail: raczk@zg.pan.krakow.pl \\ ${ }^{2}$ Institute of Geoecology and Geoinformation \\ Adam Mickiewicz University in Poznań \\ Dzięgielowa 27, 61-680 Poznań: Poland \\ e-mail: ZbZw@amu.edu.pl
}

\begin{abstract}
The paper presents the Digital Geomorphological Map of Poland (DGM) on which work started in 2013. Background is provided on the history of geomorphological mapping and the digital adaptation of analogue geomorphological maps. The legend (key symbols) of the DGM and the construction of its database are introduced. The test sheets prepared on the basis of the DGM assumptions are demonstrated.
\end{abstract}

\section{Key words}

digital geomorphological maps $\bullet$ legend $\bullet$ test sheets $\bullet$ Poland

\section{Introduction}

The idea of the geomorphological mapping of Poland was conceived by physical geographers in the 1950s when the creation of a detailed legend for a geomorphological map of Poland was begun to a plan by Klimaszewski (Klimaszewski 1953, 1956, 1963, 1982, 1990; Gilewska 1968; Starkel 2007). In the 1960s to 1990s 34 geomorphological map sheets were issued at 1:50,000 scale. They were drawn up with the use of the abovementioned legend, but adjusted to mountain and upland regions by Klimaszewski and to lowland regions by Galon (1962). The basis for the preparation of these geomorphological maps was detailed field mapping at 1:25,000 scale, which included morphometric and 
morphographic features, genesis and age of formations, as well as present-day developed landforms.

In 1980 a General Geomorphological Map of Poland was published at 1:500,000 scale. It was prepared by a Polish team of authors and edited by Starkel (1980). The legend to this map included information on the morphology and age of landforms. The following landforms were included: denudational, fluvial erosional, fluvial depositional, glacial and fluvioglacial erosional, glacial and fluvioglacial depositional, abrasive, littoral, suffosional, karst, aeolian and biogenic. This map, however, did not present anthropogenic landforms, which had been included in geomorphological sketches at 1:100,000 scale for a Detailed Geological Map of Poland (DGMP). Despite being a mandatory annex to the DGMP sheets, these sketches are not consistent in terms of their content and graphics.

In the meantime, various maps of other regions, designed at various scales and different periods of time, appeared as annexes or bases for geomorphological studies published as separate reports or articles in journals. With the development of computer-aided techniques and geographical information systems (GIS), attempts were made to digitise the existing maps. These attempts included the following regions: Torzym Plateau according to Żynda - 1964 (Mania 2005), Wielkopolska-Kujawy Lowland according to Krygowski - 1953 (Karczewski et al. 2007), Myślibórz Lakeland and Szczecin Lowland according to Karczewski - 1968 (Karczewski et al. 2008), the South-East of the Wielkopolska region and the Ostrzeszów Hills according to Rotnicki - 1966 (Bukowska et al. 2011a,b), and the island of Wolin (Lewicka et al. 2012). This resulted in principles being established concerning the digitisation of analogue geomorphological maps (Dmowska et al. 2010). The latest example of a separate numerical design is the geomorphological map of Roztocze at 1:50,000 scale designed by Buraczyński and Chabudziński (2013), the principles of which were based on the concept of Klimaszewski.
In 2013, the community of Polish geomorphologists was given a further opportunity to create a geomorphological map of the whole of Poland when the Regulation of the Council of Ministers of 3rd October 2011 on types of cartographic thematic and special maps included geomorphological maps in the group of thematic digital maps created and made available by the Surveyor General of Poland. These maps present relief formations and their genesis at reference scales as well as information on changes of landforms. The first step in the fulfilment of the Regulation was the creation of content-related, cartographic and editorial principles for a digital geomorphological map at 1:100,000 and $1: 500,000$ scale, as well as a set of sample geomorphological map sheets. The challenge was undertaken by the Association of Polish Geomorphologists (ASP) with the participation of the Institute of Geodesy and Cartography (IGC) and the GEPOL company. It was prepared by the ASP team - Z. Zwoliński (coordinator), A. Bernatek, Ł. Chabudziński, R. Dulias, M. Ewertowski, L. Gawrysiak, E. Gorczyca, J. Gudowicz, B. Izmaiłow, K. Jancewicz, J. Jania, M. Kasprzak, P. Kłapyta, K. Krzemień, M. Mazurek, A. Michno, P. Migoń, P. Molewski, A. Najwer, Z. Rączkowska, E. Rojan, E. Smolska, M. Sobucki, P. Szwarczewski, B. Szypuła, A. Tyc, P. Weckwerth, D. Wrońska-Wałach, W. Wysota; IGC - A.Wrochna, M. Brzezińska-Klusek, J. Gąsiorowski, A. Dębowska and GEPOL - P. Kokociński, R. Smyk.

\section{Principles}

The digital geomorphological map (DGM) of Poland is a database. It is composed of layers and sheets. The layer structure refers to content-related and base-related information, and the sheet structure concerns the spatial division of the map into fragments. The DGM at the scales of 1:100,000 and 1:500,000 includes the following morphogenetic groups of landforms:

- endogenous landforms,

- denudational landforms,

- glacial landforms, 
- fluvial landforms,

- karst landforms,

- aeolian landforms,

- littoral and limnic landforms,

- biogenic landforms,

- anthropogenic landforms.

Maps at scales of $1: 100,000$ and $1: 500,000$ have separate catalogues of landforms, which are always included in the nine morphogenetic groups enumerated above. Each of these is represented by a group of erosional, depositional or polygenetic formations of various ages, but without age differentiation. A total of 134 symbols were designated in the legend of the map at 1:100,000 scale, while a total of 91 symbols were designated in the legend of the map at 1:500,000 scale (Tab. 1). The principle was adopted that individual signs must be valid over the entire area of Poland and must be common to lowland, upland and mountain areas, which represented a tremendous challenge for the team designing the map.

Each landform included in the catalogue/legend for the scales of 1:100,000 and 1:500,000 has features assigned, such as a unique identification number (ID - including identification of the genetic type of the relief and the number within the morphogenetic group), Polish and English names, the type of object (areal, linear, point), quantitative feature (single form, set of forms), the type of relief, a range of geomorphometric parameters, such as area, lenght width, relative elevation, depth, slope gradient and azimuth, and the definition of a given sign. The aim of the geomorphometric parameters provided for each sign is the provision of assistance in decisions regarding the qualification of a given landform for a given map scale. Moreover, a graphic sign was created for each landform based on the principles of Gustavsson et al. (2006).

Apart from geomorphological information, the DGM at 1:100,000 scale contains additional information like the borders of the country, provinces and districts, outlines of the capitals of provinces and/or districts, national and provincial roads, selected hydrographic elements, selected height points, names and notes. The maps at a scale of 1:500,000, however, contain additional information in the form of borders of the country and provinces, outlines of the capitals of provinces, national roads, selected hydrographic information, names and notes.

The DGM consists of the following layers: base layer, thematic layers and two overlay layers. The base layer contains a shaded digital elevation model (Swiss style) and conveys topographic information. The thematic layers include:

- a basic layer containing landforms as areal objects;

- an underwater layer containing bottom formations of bays, reservoirs and a 10-mile Baltic belt;

Table 1. Quantity of signs in the morphogenetic groups at reference scales

\begin{tabular}{|l|r|c|}
\hline \multicolumn{1}{|c|}{ Morphogenetic group } & \multicolumn{2}{c|}{ Quantity of signs } \\
\cline { 2 - 3 } & Scale 1:100,000 & Scale 1:500,000 \\
\hline Endogenous landforms & 2 & 13 \\
Denudational landforms & 39 & 21 \\
Glacial landforms & 37 & 22 \\
Fluvial landforms & 20 & 12 \\
Karst landforms & 4 & 4 \\
Aeolian landforms & 9 & 6 \\
Littoral and limnic landforms & 9 & 1 \\
Biogenic landforms & 1 & 7 \\
Anthropogenic landforms & 13 & 7 \\
\hline
\end{tabular}


- overlay layer 1, containing selected exceptional landforms;

- overlay layer 2, containing landforms as linear and point objects.

In addition, the overlay layers cover the surface waters of rivers, inland reservoirs and the sea, as well as a cartographic grid.

A digital geomorphological map is to be used in the current spatial management of the country, and the legend has therefore been designed with reference to contemporary relief transformations, particularly those caused by human activity. The catalogues of landforms for a given scale include those critical and most common anthropogenic landforms which transform the natural topographic relief. The mapping does not include areas undergoing natural processes of contemporary land modelling owing to the generalisation of such phenomena being too large at reference scales.

The DGM is included in the spatial information network through metadata prepared specifically for geomorphological maps. It contains 32 elements in profile and constitutes one of the parts of the national land surveying and cartographic resources.

\section{Digital geomorphological map of Poland: Test sheets}

Based on the principles adopted for the DGM, test areas were selected for reference mapping (Fig. 1) in accordance with the morphogenetic zones distinguished by Gilewska (1991). These were:

- high-mountain area - the Tatra Mountains;

- mountain area - the Karkonosze Mountains;

- upland areas - Roztocze, Kraków Upland, Silesian Upland (area of strong anthropogenic impact);

- lowland old glacial area - Kutno Plain;

- lowland young glacial area - ChełmnoDobrzyń Lakeland;

- coastal area - the island of Wolin and the Szczecin Lowland.

DGM sheets at the scale of $1: 100,000$ and 1:500,000 have been prepared for each test area. Each sheet is a database with

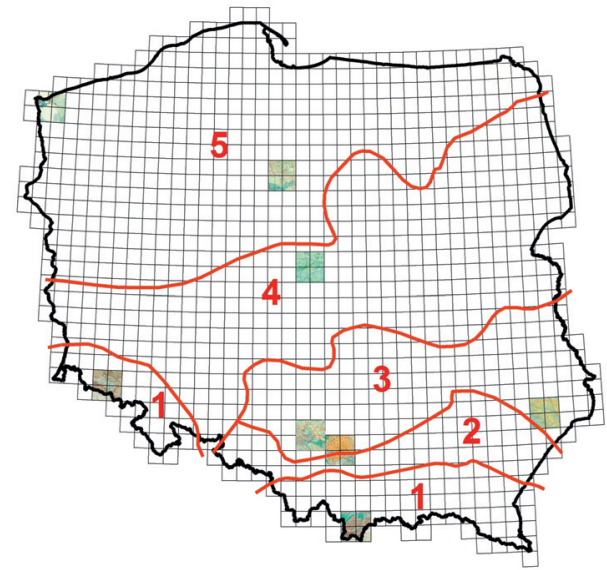

Figure 1. Distribution of the test Digital Geomorphological Map sheets already prepared on a background of morphogenetic zones in Poland (according to Gilewska 1991): 1 - mountains; 2 - intermountain basins; 3 - uplands and old mountains; 4 - old-postglacial zone; 5 - youngpostglacial zone

information on landform identification and characteristics, morphometry and morphology. Information concerning landform identification covers the following parameters: object identification number (serial number in the database), landform identification number and name of landform according to the catalogue. The characteristics contain information connected with morphogenetic type of relief and whether the formation is a single form or a set of landforms. The morphometric parameters are equivalent to those in the landform catalogue. The geomorphological description contains notes presented in groups relating to morphology, morphogenesis and morphochronology.

Test sheets are consistent with the contour intervals at the scale of 1:50,000. The sheets have been prepared on the basis of reports found in geomorphological and geological literature concerning a given area, as well as the expertise of map authors. Metadata, containing the list of information sources, have been prepared for each sheet. Figure 2 presents examples of sheets for different regions in Poland. 
The sheets prepared so far demonstrate that the use of a common legend for the entire area of Poland has not affected proper representation of the relief (Fig. 2). The maps presented in Figure 2G,H show differences in the mountain relief between the areas of old fault-block mountains and young fold mountains, as well as the glacial elements of high mountain relief. Similarly differences and affinity in the postglacial landforms for young (Weichselian) and old (Saalian) postglacial relief are demonstrated in Figure 2B,C. In Figure $2 \mathrm{~A}$ there is also part of a map of young (Weichselian) postglacial relief in a seaside location. Three other sections of digital geomorphological maps (Fig. 2D,E,F) show differentiation between types of upland relief in Poland.

\section{Concluding remark}

The DGM is planned to be the first digital geomorphological map for the entire area of Poland. It should be completed by the year

\section{References}

Bernatek A., Gorczyca E., IzmalŁow B., KŁapyta P., Krzemień K., Michno A., Sobucki M., Wrońska-WAŁACH D., 2013. Cyfrowa mapa geomorfologiczna. Kraków Zachód: 1:100,000. Warszawa: Główny Geodeta Kraju.

Bukowska A., Jasiewicz J., RotniCKI K., 2011 a. Geomorfologia południowo-wschodniej Wielkopolski w skali 1:200,000. Poznań: Instytut Geoekologii i Geoinformacji. Uniwersytet im. Adama Mickiewicza.

Bukowska A., Jasiewicz J., RotNiCKI K., 2011 b. Geomorfologia Wzgórz Ostrzeszowskich w skali 1:75,000. Poznań: Instytut Geoekologii i Geoinformacji. Uniwersytet im. Adama Mickiewicza.

Buraczyński J., Chabudziński Ł., 2013. Mapa geomorfologiczna Roztocza w skali 1: 50,000. 9 sheets, Lublin: Wydział Nauk o Ziemi i Gospodarki Przestrzennej. Uniwersytet im. Marii Curie-Skłodowskiej.

Buraczyński J., GaWrysiak L., Chabudziński Ł., 2013. Cyfrowa mapa geomorfologiczna. Toma-
2020. This will produce a current, uniform and consistent database with information on the relief of Poland at the scales of 1:100,000 and 1:500,000. The uneven distribution of geomorphological studies conducted in various places in Poland will be a considerable obstacle to the preparation of further sheets of the map.

\section{Acknowledgment}

The authors would like to express sincere thanks to all participants of in the regional geomorphological-geoinformation teams for their fieldwork on digital geomorphological maps.

Editors' note:

Unless otherwise stated, the sources of tables and figures are the authors' on the basis of their own research.

szów Lubelski w skali 1:100,000. Warszawa: Główny Geodeta Kraju.

DMowskA A., Gudowicz J., Zwoliński Z., 2010. Cyfrowa adaptacja analogowych map geomorfologicznych. Landform Analysis, 12, pp. 35-47.

GALON R., 1962. Instrukcja do szczegółowej mapy geomorfologicznej Polskiego Niżu 1:50,000. Toruń: Zakład Geomorfologii i Hydrografii Niżu. Instytut Geografii PAN.

GILEWSKA S., 1968. Project of the unified key to the detailed geomorphological map of the world. Folia Geographica. Series Geographica-Physica, 2, Kraków: Polska Akademia Nauk. Komisja Geograficzna.

GILEWSKA S., 1991, Rzeźba [in:] L. Starkel (ed.), Geografia Polski: Środowisko przyrodnicze. Warszawa: Państwowe Wydawnictwo Naukowe, pp. 248-296.

Gustavsson M., Kolstrup E., Seijmonsbergen A.C., 2006. A new symbol-and-GIS based detailed geomorphological mapping system: Renewal of a scientific discipline for understanding landscape 
development. Geomorphology, vol. 77, no. 1-2, pp. 90-111.

Jania J., Dulias R., Szyputa B., Tyc A., 2013. Cyfrowa mapa geomorfologiczna. Katowice w skali 1:100,000. Warszawa: Główny Geodeta Kraju.

Karczewski A., Mazurek M., Stach A., ZwolińSKI Z., 2007. Mapa geomorfologiczna Niziny Wielkopolsko-Kujawskiej w skali 1:300,000 wersja numeryczna pod redakcja B. Krygowskiego. Poznań: Instytut Paleogeografii i Geoekologii. Uniwersytet im. Adama Mickiewicza.

Karczewski A., Dmowska A., Stach A., GudowICZ J., ZwolińskI J., 2008. Geomorfologia Pojezierza Myśliborskiego i Niziny Szczecińskiej: 1:200,000 - A. Karczewski. Poznań: Instytut Paleogeografii i Geoekologii. Uniwersytet im. Adama Mickiewicza.

KARCZEWSKI A., Zwoliński Z., 2013. Cyfrowa mapa geomorfologiczna. Świnoujście w skali 1:100,000. Warszawa: Główny Geodeta Kraju.

KLIMASZEWSKI M., 1953. The problem of the geomorphological field mapping of Poland. Przeglad Geograficzny, vol. 25, no. 3, pp.16-23.

KLIMASZEWSKI M., 1956. The principles of geomorphological survey of Poland. Przeglad Geograficzny, 28, pp.32-40.

KLIMASzewski M., (ed.), 1963. Problems of geomorphological mapping. Geographical Studies, 46, Warsaw: Institute of Geography PAS.

KLIMASZEWSKI M., 1982. Detailed geomorphological maps. ITC Journal, 3, pp. 265-271.

KLIMASzEWSKI M., 1990. Thirty years of detailed geomorphological mapping. Geographia Polonica, 58, pp.11-18.

Lewicka J., Zwoliński Zв., Soldati M., 2012. Mapa geomorfologiczna wyspy Wolin. Poznań:
Instytut Paleogeografii i Geoekologii. Uniwersytet im. Adama Mickiewicza.

ManiA W., 2005. Numeryczna mapa geomorfologiczna Wysoczyzny Torzymskiej [in:] A. Kijowski, J. Kijowska, L. Kozacki, W. Mania (eds.), Środowisko przyrodnicze Ziemi Lubuskiej. Wybrane zagadnienia. Sesja naukowa dedykowana prof. dr hab. Stefanowi Żyndzie z okazji 50-lecia pracy naukowej, dydaktycznej i organizacyjnej, Poznań: Oficyna, pp. 99-104.

Migoń P., Kasprzak M., Jancewicz K., 2013. Cyfrowa mapa geomorfologiczna. Jelenia Góra w skali 1:100,000. Warszawa: Główny Geodeta Kraju.

Molewski P., Weckwerth P., Wysota W., 2013. Cyfrowa mapa geomorfologiczna. Kutno w skali 1:100,000. Warszawa: Główny Geodeta Kraju.

Отто J-Ch., Sмітн M.J., 2013. Section 2.6: Geomorphological mapping [in] L.E. Clarke, J.M. Nield (eds.), Geomorphological techniques (online edition). London: British Society for Geomorphology, pp. 1-10.

RĄCZKOWSKA Z., 2013. Cyfrowa mapa geomorfologiczna. Nowy Targ-Płd. w skali 1:100,000. Warszawa: Główny Geodeta Kraju.

Starkel L., (ed.), 1980. Przegladowa Mapa Geomorfologiczna Polski: 1:500,000. Warszawa: Instytut Geografii i Przestrzennego Zagospodarowania PAN.

Starkel L., 2007. Koncepcja kartowania geomorfologicznego profesora Mieczysława Klimaszewskiego. Prace Komisji Paleogeografii Czwartorzędu PAU, Kraków, 7, pp. 65-70.

Weckwerth P, Molewski P., Wysota W., 2013. Cyfrowa mapa geomorfologiczna. Toruń w skali 1:100,000. Warszawa: Główny Geodeta Kraju. 

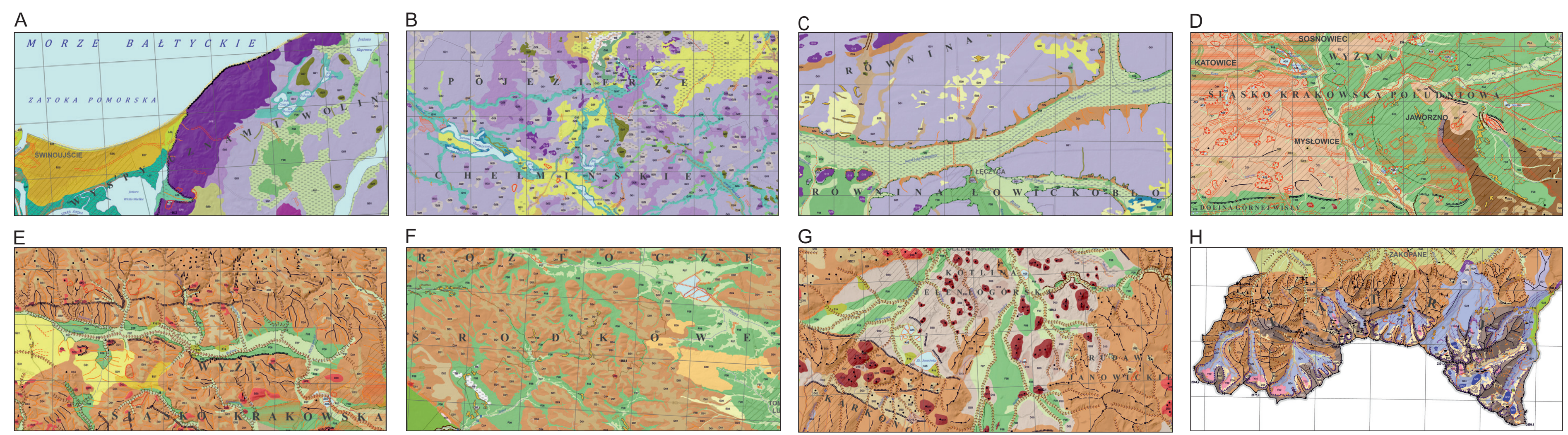

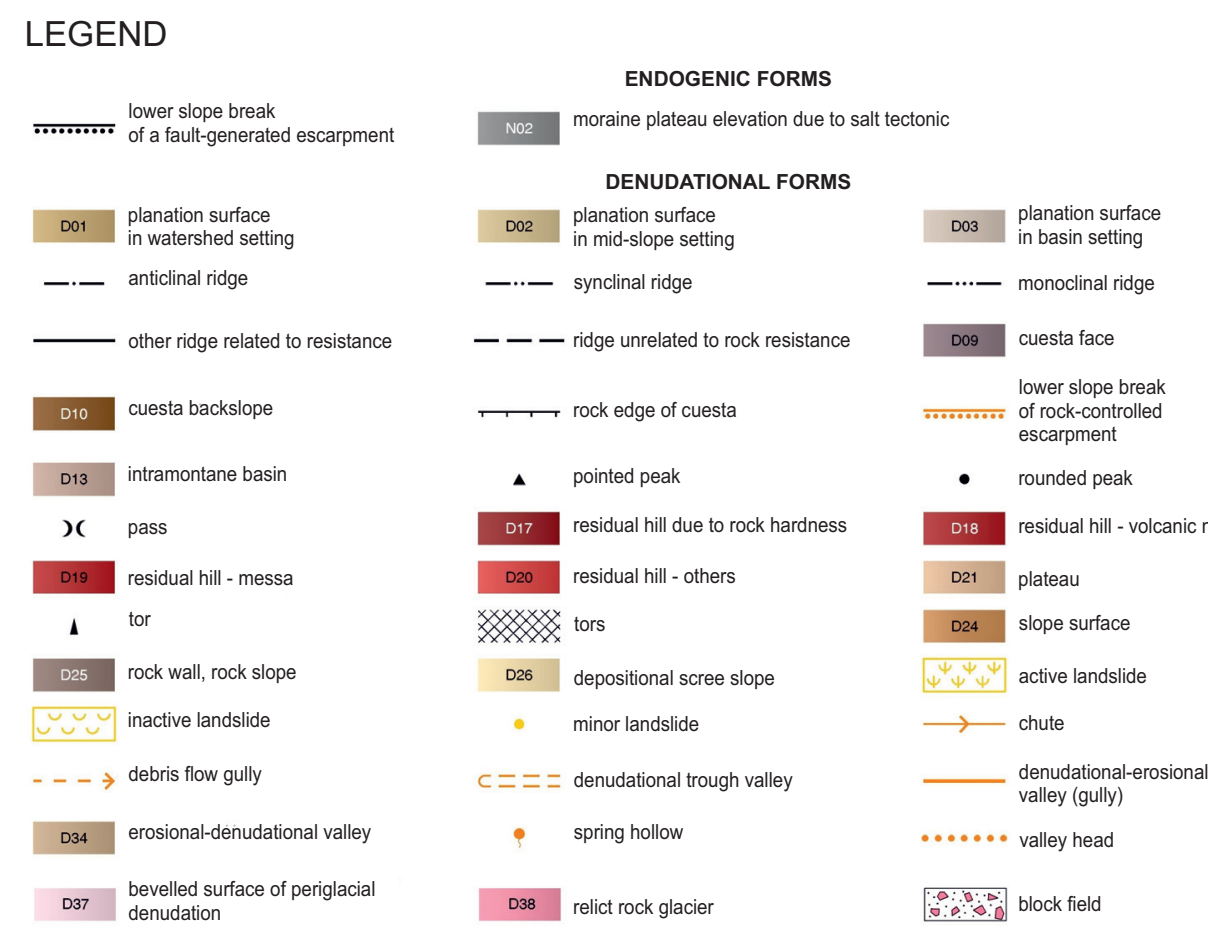

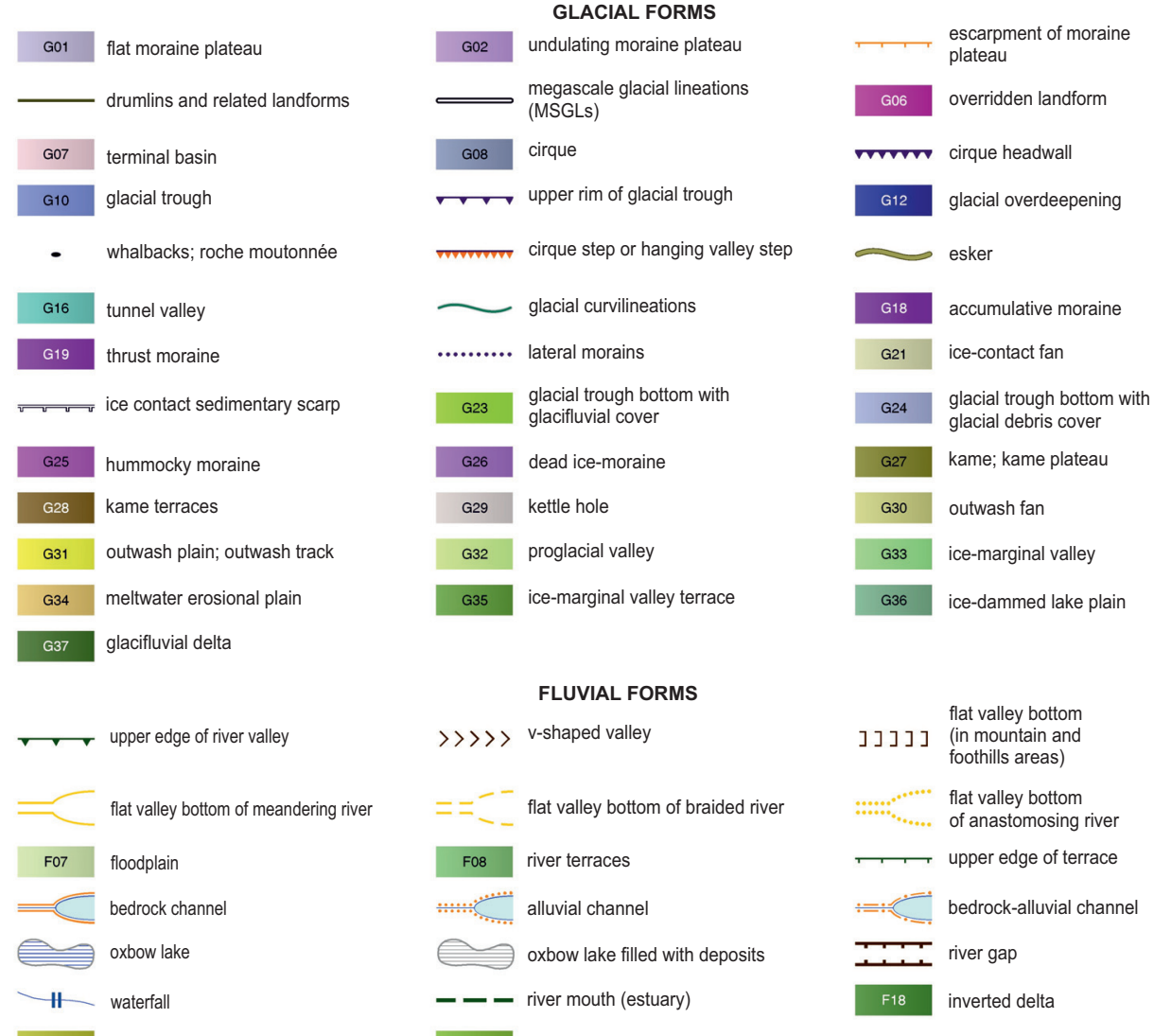

kol karst depression

- cave

E01 wind roroded sandy hillex

stabilised dure

Ev7 dune plain

.......... sand bars; sandbanks

chos dead cliff

Lo7 regressive detta

$=\overline{=}=\overline{=}=$ biogenic plain

$\rightarrow$ excavations; opencast pits

anthropogenic flat

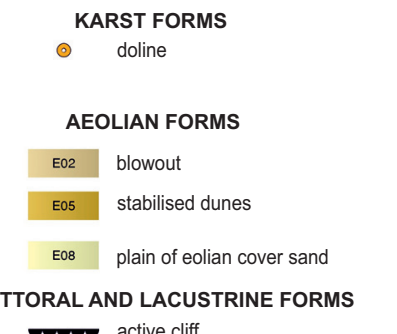

active cliff

tos

Los
BIOGENIC FORMS

\section{ANTHROPEGNIC FORMS}

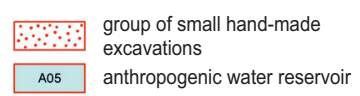

$\underset{n}{\longrightarrow}$ dumps

dam; dike

(1)

Figure 2. Digital Geomorphological Map test sheets at 1:100,000 scale for: A - coastal area - Swinoujście (Karczewski \& Zwoliński 2013); B - young-glacial area - Toruń (Weckwerth et al. 2013); C - old-glacial area - Kutno (Molewski et al. 2013); D - upland area
transformed by strong anthropogenic impact - Katowice (Jania et al. 2013); E - upland area - Kraków Zachód (Bernatek et al. 2013); F - upland area - Tomaszów Lubelski (Buraczynílict 